\title{
Scandinavian cinema culture and archival practices: collecting, curating and accessing moving image histories
}

\section{Dagmar Brunow and Ingrid Stigsdotter}

Film historians have long used the archive as a source for their research. The role of the archive itself, however, has often been obscured. The archive, meanwhile, has become a buzzword in the arts and humanities. Theorizations of the archive oscillate between a focus on the power dimensions on the one hand and its materiality on the other. One of the most urgent questions is the preservation of analogue stock. At the same time, archives are not storehouses of neutral material, but play a crucial role in the construction of 'historical sources', of documents through selection, classification and categorization, for instance through metadata. An agent in its own right, the archive entails a performative dimension in constructing documents and sources and, as a consequence, in creating the grounds from which history is written. Archival practice and research can intervene into a film historiography that has highlighted some filmmakers while marginalising others. Creating access is of vital importance, as a film needs to stay in circulation to be remembered. Cultural memory, which is always mediated, is constructed in the process of reception and through the narratives that evolve. This is why archives need to create access to their audio-visual material.

In recent years, digitization has inspired many projects aiming at increasing and improving access to film archival collections in different ways, with examples involving Scandinavian archives including Danmark på Film, Filmarkivet.se (and the related Filmarkivforskning,se), Filmarkivet.no, Yle’s Arkivet and the European Film Gateway. Modes of curating access to digitized content are examined in current research projects such as the Horizon 2020 action on I-Media-Cities (2016-18) and 'The Cultural Memory of Moving Images', financed by the Swedish Research Council (2016-18). The role of women behind the camera is highlighted via the digital knowledge bank Nordic Women in Film. Such developments are likely to affect film historiography.

At this point, and against this background, we find it timely to present a special issue that brings together scholarship on film and film related archives and archiving 
practices, theoretical and practical approaches to the relationship between moving images and the archive, and media archaeology, all within the specific context of Scandinavian cinema culture. The articles explore a wide range of topics, types of films and collections, reflecting the fact that film archives, at least in theory, could preserve and facilitate access to all kinds of film histories.

Lars Gustaf Andersson's and John Sundholm's feature article highlights that power dynamics and status hierarchies are always implicitly (and sometimes explicitly) at play in archival practices of collecting, storing, distributing and displaying artefacts. The 'minor cinema' that they discuss is still waiting to be acknowledged by the archives, and as their article as well as Maria Fosheim Lund's demonstrate, scholarly interventions into archival practices are important. Fosheim Lund tells the story of tracing and collecting fan ephemera and promotional material from the silent era online in order to ensure that the Norwegian actress Aud Egede-Nilsson, whose own production company made around 30 films between 1916 and 1920, is represented in the film archival collections of the National Library of Norway.

Both Claire Thompson and Petúr Valsson engage with the work of Danish auteur Lars von Trier, but with very different approaches. Valsson's short subject uses Derrida's concept of archive fever and von Trier's foregrounding of medial materiality to discuss 'the anarchivistic disposition of cinema', focusing on von Trier's interest in image decay and digital technology. In Thompson's article, von Trier's work adapting Carl Th. Dreyer's screenplay 'Medea' for television becomes the starting point for a playful discussion around non-filmic materials in the archive, leading to an exploration of the notion of the 'unfilmed film' that Thompson places in an interesting relationship with von Trier's performance of his own status as auteur.

Thompsons's reflections are grounded in her own experiences working with nonfilmic artefacts in the archives of the Danish Film Institute, and in this sense show an affinity with Anne Bachmann's short piece on press cuttings, with particular focus on the collections held at the Film Library at the Swedish Film Institute. Bachmann contextualizes the practice of keeping press cuttings, shedding light on paradigmatic shift from yesterday's carefully curated collections of cuttings and today's mass digitization projects and the consequences this might have for film historiography.

Pelle Snickars and Fredrik Norén deal with one particular type of digitized archival materials, Swedish governmental reports known as SOUs. The authors show how such 
materials can be 'distant read' through computerized analysis of large text corpora, and argue that the topic modelling and visualization methods demonstrated in their article could help researchers gain an overview of research topics covered in digitized text corpora as well as lead to new types of research questions and findings.

Erik Florin Persson approaches municipally sponsored films of the city of Gothenburg as examples of what Charles R. Acland and Haidee Wasson term 'useful cinema'. Persson's article emphasizes the importance of using local archives rather than relying exclusively on national archival collections when examining these kinds of films, demonstrating how the inclusion of local archival materials affects not only our understanding of Scandinavian film production, but also of international film circulation.

Mariah Larsson and Anna Sofia Rossholm present a collection of films, The Face of AIDS Archive, which could arguably also be seen as 'useful cinema', since it consists of documentation about HIV/AIDS that has been commissioned by the medical university Karolinska Institutet in Stockholm. This collection differs, however, from most 'useful cinema' in that it also has a strong authorial dimension, having been shot by the Swedish filmmaker Staffan Hildebrand, who has donated his footage to Karolinska and is still strongly involved in the project.

Different approaches to documenting Swedish realities are particularly well represented in this issue, ranging from the impact of HIV and AIDS in Larsson's and Rossholm's piece, propagandistic presentations of Gothenburg in Persson's article, or immigrant filmmakers' portraits of Stockholm in Andersson's and Sundholm's article. But we have also wanted to explore the relationship between filmic documentation and archives through the eyes of film practitioners, and we are therefore very pleased to include an interview section where six contemporary Swedish film practitioners - Kersti Grunditz, Maud Nycander, Jannike Åhlund, Dominika Daubenbüchel, Stig Björkman and Petra Bauer - answer questions about using archives and archival material in their work.

Harry Schein, the former head of the Swedish Film Institute, is at the centre of the documentary Citizen Schein (2016), directed, written and edited in a collective endeavour by Kersti Grunditz, Maud Nycander, and Jannike Åhlund. Citizen Schein makes extensive use of archival footage to convey a multi-layered narrative, allowing for valuable insights into the workings of Swedish film politics at the heydays of the welfare state. For their documentary Jag är Ingrid (Ingrid Bergman: In her Own Words) (2016) 
Stig Björkman, Dominika Daubenbüchel and Stina Gardell were given access to Ingrid Bergman's private film archive. The footage conveys a more complex understanding of the Hollywood legend, adding more nuances to Bergman's star persona. In their conversations with Ingrid Stigsdotter and Dagmar Brunow, the filmmakers behind these two critically lauded documentaries talk about their use of archival footage, ethical considerations, legal issues and the role of sound. Finally, internationally acclaimed video artist Petra Bauer, who holds a chair at the Royal Academy of Art, speaks about her uses of the archive in works that explore questions of authorship, social protest and historiography from a feminist and post-colonial perspective.

This special issue compiles current tendencies in film studies by emphasizing the importance of the archive, not only as a mere source for historical research, but as an actor in itself. It also opens up for further theorizations of and perspectives on the archive. 